\title{
Multiple-trait random regression models for the estimation of genetic parameters for milk, fat, and protein yield in buffaloes
}

\author{
Rusbel Raul Aspilcueta Borquis, ${ }^{*}$ Francisco Ribeiro de Araujo Neto, ${ }^{*}$ Fernando Baldi, ${ }^{*}$ \\ Naudin Hurtado-Lugo, ${ }^{*}$ Gregório M. F. de Camargo, ${ }^{*}$ Milthon Muñoz-Berrocal, $†$ and Humberto Tonhati* $\ddagger^{1}$ \\ *Department of Animal Science, São Paulo State University, Jaboticabal, SP, Brazil, 14884900 \\ †Universidad Nacional Agraria de la Selva, Aptdo. 156, UNAS-Tingo Maria-Peru \\ ¥Conselho Nacional de Desenvolvimento Científico e Tecnologico and Instituto Nacional de Ciência e Tecnologia - Ciência Animal, Viçosa, MG, \\ Brazil, 36570000
}

\section{ABSTRACT}

In this study, genetic parameters for test-day milk, fat, and protein yield were estimated for the first lactation. The data analyzed consisted of 1,433 first lactations of Murrah buffaloes, daughters of 113 sires from 12 herds in the state of São Paulo, Brazil, with calvings from 1985 to 2007. Ten-month classes of lactation days were considered for the test-day yields. The (co)variance components for the 3 traits were estimated using the regression analyses by Bayesian inference applying an animal model by Gibbs sampling. The contemporary groups were defined as herd-year-month of the test day. In the model, the random effects were additive genetic, permanent environment, and residual. The fixed effects were contemporary group and number of milkings (1 or 2 ), the linear and quadratic effects of the covariable age of the buffalo at calving, as well as the mean lactation curve of the population, which was modeled by orthogonal Legendre polynomials of fourth order. The random effects for the traits studied were modeled by Legendre polynomials of third and fourth order for additive genetic and permanent environment, respectively, the residual variances were modeled considering 4 residual classes. The heritability estimates for the traits were moderate (from 0.21-0.38), with higher estimates in the intermediate lactation phase. The genetic correlation estimates within and among the traits varied from 0.05 to 0.99 . The results indicate that the selection for any trait test day will result in an indirect genetic gain for milk, fat, and protein yield in all periods of the lactation curve. The accuracy associated with estimated breeding values obtained using multi-trait random regression was slightly higher (around 8\%) compared with single-trait random regression. This difference may be because to the greater amount of information available per animal.

Received August 8, 2012.

Accepted April 4, 2013.

${ }^{1}$ Corresponding author: tonhati@fcav.unesp.br
Key words: covariance functions, heritability, Legendre polynomials

\section{INTRODUCTION}

Buffalo milk is an important source of nutrients because it contains higher percentages of protein and fat than cattle milk, with a fat content varying from 6.87 to $8.59 \%$ and a protein content varying from 3.91 to 4.55\% (Rosati and Van Vleck, 2002; Aspilcueta-Borquis et al., 2010a). This richness confers particularities to the production, yield, and quality of products derived from fresh buffalo milk. Currently, the dairy industry favors milk containing high levels of solids, as most of milk is processed into dairy products (yogurt, cheese, and so on), a fact that makes buffalo milk a profitable alternative.

Milk yield records and their components measured along the lactation provide a typical example of repeated measurements or longitudinal data (measurements obtained sequentially from the same animal over time). The main feature of longitudinal data is the evaluation of the genetic properties of one or more variables across a specific dimension, such as time or space (Wiggans and Goddard, 1997). Several studies showed that random regression models (RRM) are an appealing approach to model repeated measurements and to estimate genetic parameters for these traits (Schaeffer and Jamrozik, 2008; Sesana et al., 2010).

In contrast to multi-trait models (finite-dimensional models) that provide point predictions, RRM permit the prediction of breeding values for the lactation curve as a whole, for any point or interval within the lactation period, and for functions of the lactation curve (Jamrozik et al., 1997). In dairy cattle, the regressions are fitted as a function of the lactation period using a base function that permits modeling of the trajectory for both the population mean (fixed regression) and each animal (random regression). Another advantage of $\mathrm{RRM}$ is that the covariance structure between measures 
Table 1. Descriptive statistics of the test-day data of milk, fat, and protein yield

\begin{tabular}{lccc}
\hline Item & $\begin{array}{c}\text { Milk } \\
\text { yield }\end{array}$ & $\begin{array}{c}\text { Fat } \\
\text { yield }\end{array}$ & $\begin{array}{c}\text { Protein } \\
\text { yield }\end{array}$ \\
\hline Observations (n) & 10,983 & 10,691 & 10,691 \\
Sires (n) & 113 & 113 & 113 \\
Cows (n) & 1,433 & 1,433 & 1,433 \\
Mean (kg) & 6.08 & 0.38 & 0.24 \\
SD (kg) & 2.32 & 0.14 & 0.09 \\
Minimum (kg) & 1.0 & 0.07 & 0.05 \\
Maximum (kg) & 14.40 & 0.87 & 0.54 \\
CG & 708 & 676 & 676 \\
\hline
\end{tabular}

${ }^{1} \mathrm{CG}=$ contemporary group.

can be characterized by a function, a fact that permits greater flexibility in the use of longitudinal data (Van Der Werf and Schaeffer, 1997).

Although, several studies report genetic parameter estimates for test-day milk yield records and their components obtained by RRM in dairy cattle (Schaeffer and Jamrozik, 2008) and buffaloes (Breda et al., 2010; Sesana et al., 2010; Aspilcueta-Borquis et al., 2010b), few studies apply multi-trait random regression for test-day milk, fat, and protein yield (Muir et al., 2007; Hammani et al., 2008). The implementation of a multitrait random regression in dairy is attractive because it allows for the study of the genetic relationships between milk volume and milk components along the lactation. According to Hammani et al. (2008), the multiple-trait RRM for simultaneous analysis of all yields seems to be a logical choice. In buffaloes, this issue is very important, as buffalo milk is valued by constituents and the lactation curve in buffaloes is different from that observed in cattle, from a biological point of view. Compared with dairy cattle, total milk yield of buffaloes is lower, the lactation length is shorter, and the lactation peak is less accentuated. In view of the possibility to use RRM and of the importance of milk components for buffalo farming, studies investigating the association between test-day milk, protein, and fat yield along the lactation are needed. Therefore, the objective of the present study was to estimate (co)variance components for first lactation milk, fat, and protein yield by single and multi-trait RRM using Bayesian methods.

\section{MATERIALS AND METHODS}

In the present study, milk, fat, and protein yield testday records from 1,433 first lactation Murrah buffaloes, daughters of 113 sires, were analyzed. The buffaloes had calved between 1985 and 2007 and belong to 12 herds from the state of São Paulo, Brazil. The milking test controls were performed monthly, keeping the calves at dams to stimulate milk production.

The milk yield records were obtained starting on the fifth day after calving and were truncated at $305 \mathrm{~d}$ of lactation, as only $12 \%$ of females had a lactation length greater than this period. Only buffaloes that had their first test-day record before $45 \mathrm{~d}$ after calving were considered in the analyses. The test-day productions were considered in monthly lactation classes, varying from 1 to 10 classes, and included animals with at least 4 tests. The contemporary groups were defined as herd-yearmonth of milk test, with the restriction that each group had to contain at least 4 animals. After data editing, the descriptive statistics for milk, fat, and protein yield along the lactation (first lactation) are shown in Table 1. A pedigree file containing 2,092 animals was used in all the analyses.

Single-trait and 3-trait RRM (monthly test-day for milk, fat, and protein yield) were used for the analysis. The model included contemporary group and number of milkings per day (1 or 2 levels) as fixed effects, age of buffalo at calving (linear and quadratic effects) as covariate, and the average lactation curve of the population, which was modeled using a fourth-order orthogonal polynomial. The additive genetic, permanent environmental, and residual effects were included as random effects. To model additive genetic and permanent environmental random effects for all traits, third- and fourth-order Legendre polynomials were used. Residual variances were modeled using a step function with 4 classes as follows: 1,2 to 3,4 to 8 , and 9 to $10 \mathrm{mo}$ of lactation. The order of polynomials and residual classes applied were defined based on preliminary single-trait RRM analyses.

The (co)variance components were estimated by Bayesian inference using the Gibbs sampler of the GIBBS3F90 program (Misztal, 2010). The matrix representation of the model can be described as

$$
\mathbf{y}=\mathbf{X} \boldsymbol{\beta}+\mathbf{Z} \mathbf{a}+\mathbf{W} \mathbf{p}+\mathbf{e},
$$

where $\mathbf{y}$ is the vector of phenotypic records (milk, fat, and protein yield); $\boldsymbol{\beta}, \mathbf{a}, \mathbf{p}$, and $\mathbf{e}$ are vectors of fixed effects, additive genetic coefficients, permanent environmental coefficients, and residual coefficients, respectively; and $\mathbf{X}, \mathbf{Z}$, and $\mathbf{W}$ are incidence matrices relating 
$\boldsymbol{\beta}$, $\mathbf{a}$, and $\mathbf{p}$ to $\mathbf{y}$. Uniform a priori distributions were assumed for the fixed effects, Gaussian distributions for genetic and permanent environmental coefficients, and the inverse Wishart distribution for the variance components:

$$
\begin{gathered}
\beta \propto \text { constant, } \\
a \mid k_{a} \sim N\left[0,\left(k_{a} \otimes \mathbf{A}\right)\right], \\
p \mid k_{p} \sim N\left[0,\left(k_{p} \otimes \mathbf{I}\right)\right], \\
k_{a} \mid S_{a}, v_{a} \sim I W\left[S_{a} v_{a}, v_{a}\right], \\
k_{p} \mid S_{p}, v_{p} \sim I W\left[S_{p} v_{p}, v_{p}\right],
\end{gathered}
$$

where $k_{\mathrm{a}}$ and $k_{\mathrm{p}}$ are (co)variance matrices between random regression coefficients for additive genetic and permanent environmental effects of the animal, respectively; $\mathbf{A}$ is an additive relationship matrix; $\mathbf{I}$ is an identity matrix whose order is equal to the number of animals with records; $S_{a}$ and $v_{a}$ and $S_{p}$ and $v_{p}$ are the values of a priori and degree of freedom for additive genetic and permanent environmental effects, respectively. For the $i$ th class of residual variance, considered for the single and multiple traits, analyses were sampled from, inverted Chi-Square and inverted Wishart distributions:

$$
\begin{gathered}
\sigma_{e-i}^{2} \mid S, v \sim \chi^{-2}(S, v), \\
R_{i} \mid S, v \sim I W[S v, v],
\end{gathered}
$$

where $v$ and $S$ are the degree of freedom and the a priori values for residual variance at class $i$ in the single-trait analyses or the residual (co)variance matrix at class $i$ in the multi-trait analyses.

A chain length of 1,000,000 cycles was established, with a burn-in period of 100,000 cycles, and a sampling interval of 100 cycles, corresponding to 9,000 samples for subsequent analysis. The variance and heritability estimates for each test day and correlations between test days were obtained by covariance functions estimated in each cycle. For each parameter, a posterior distribution was obtained by the Heidelberger and Welch test (Heidelberger and Welch, 1983). A burn-in period was determined for each parameter using the samples obtained with the GIBBS3F90 software. After subsequent elimination of this period, for the description of posterior distributions, the mean was used as a point estimate and the highest posterior density interval $(95 \%)$ as a measure of dispersion.

The breeding values and their reliabilities were estimated for accumulated milk, fat, and protein yield to 305-d (MY305, FY305, and PY305, respectively). The breeding values and their reliabilities were obtained from the a posteriori distribution of random regression coefficient estimates. For each trait, the breeding value $\left(\mathbf{E B V}_{j t}\right)$ of animal $j$ at test day $t$ can be obtained as:

$$
\mathrm{EBV}_{j t}=\mathbf{C}_{\mathbf{t}} \hat{\mathbf{a}}_{\mathbf{j}}
$$

where $\mathbf{C}_{\mathbf{t}}$ is a row vector of Legendre polynomial covariables for test day $t$ of lactation; and $\hat{\mathbf{a}}_{\mathbf{j}}$ is a column vector with breeding values for covariance function coefficients. With this information, the breeding values for MY305, FY305, and PY305 were predicted using the following formula:

$$
\mathrm{EBV}_{305}=\sum_{t=5}^{305} \mathrm{EBV}_{j t}
$$

The breeding values obtained with multi- and singletrait RRM were compared through the rank correlations and reliabilities obtained with both models. The accuracy estimates were obtained according to Meyer (2004). The predicted error variance (PEV) of random regression coefficients were obtained from the a posteriori distribution (Gonzales-Récio et al., 2006). Thus, the accuracy of a random regression coefficient for any animal can be obtained with the formula

$$
r=\sqrt{1-\mathrm{PEV} / \text { Var }},
$$

where Var is the random regression coefficient variance of the genetic additive covariance function. After that, the accuracies for each test day were calculated, and the accuracy for MY305, FY305, and PY305 was obtained from the averaging the accuracy of all test days.

\section{RESULTS AND DISCUSSION}

\section{Post-Gibbs Analysis}

The stationarity test (Heidelberger and Welch, 1983) showed that, in the case of some parameters, a larger number of cycles needed to be discarded to obtain a stable chain. This additional burn-in might be explained by the large number of parameters to be estimated with this model (147), which impaired convergence of the chain (Wang et al., 1993). However, the number of remaining samples $(3,600-9,000)$ was sufficient to describe the posterior distribution of the parameters estimated. In addition, a high interdependence between samples was observed, resulting in a variable number of effective samples depending on the parameter analyzed (Table 2 and Figure 1). 

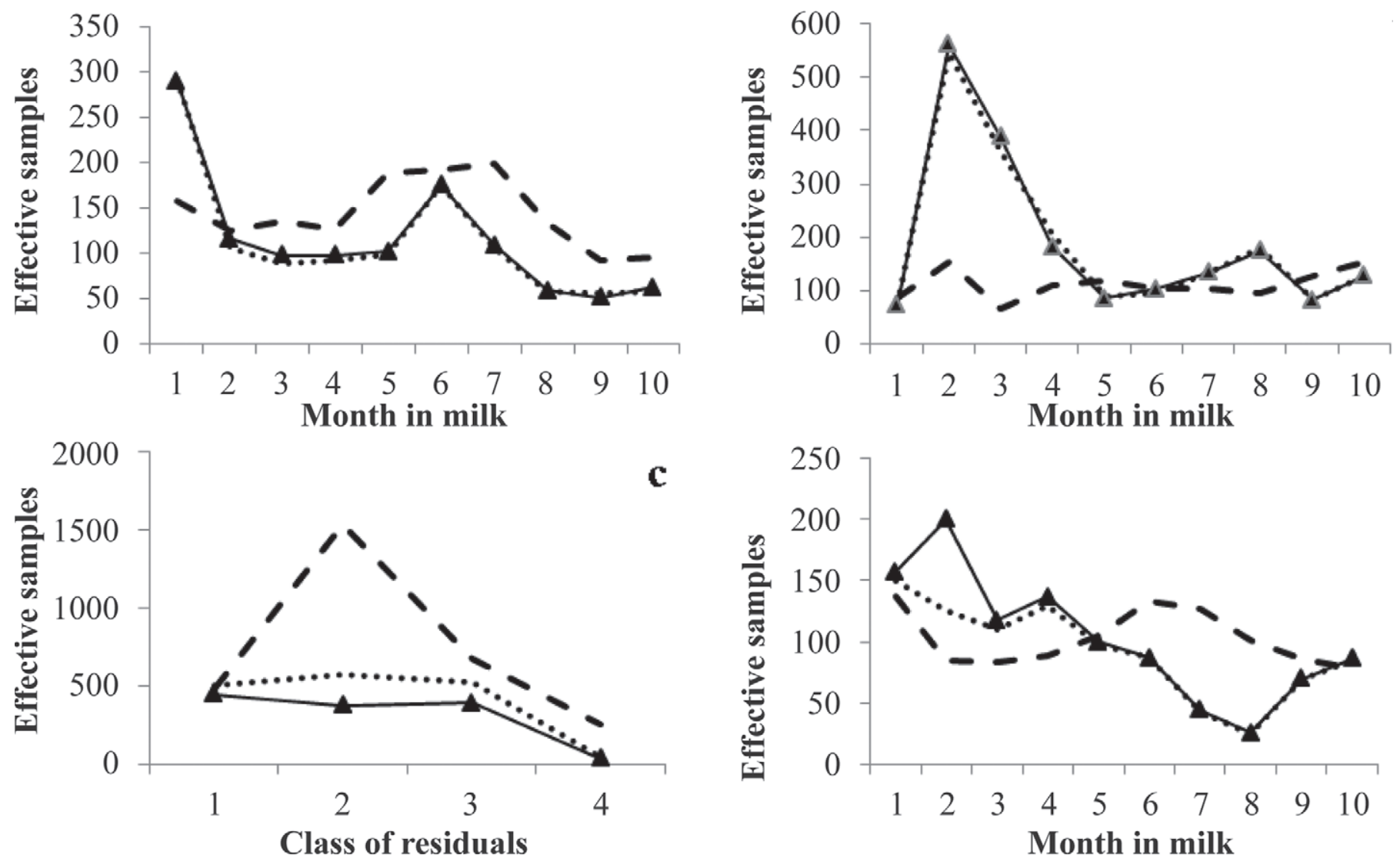

Figure 1. Number of effective samples for estimates of additive genetic variances (a), permanent environment variance (b), residual variance (c), and heritability (d) for milk $(--)$, fat $(\cdot)$, and protein $(\boldsymbol{\Lambda})$ test-day yield.

With respect to the reliability of the estimates (demonstrated by the standard deviation and highest posterior density intervals), variation was observed according to the type of information available for parameter estimation. In many cases, the estimates obtained for test days at the end of lactation tended to show wider highest posterior density intervals, possibly because of the fewer number of records. The same was observed for some of the correlation estimates, both genetic and permanent environmental correlations (data not shown).

\section{Estimates of Variances and Genetic Parameters}

With respect to the order of polynomials used, Pool et al. (2000) showed that the (co)variance structure of lactation curves can be modeled with sufficient precision using third-order polynomials for genetic effects and fourth-order polynomials for permanent environmental effects. Lopez-Romero and Carabaño (2003) also suggested low-order polynomials for additive genetic effects and higher-order polynomials for permanent environmental effects to be the most adequate.

Table 2. Mean, minimum, and maximum of the effective number of samples for each estimated parameter

\begin{tabular}{lrrc}
\hline Component (n) & Mean & Maximum & Minimum \\
\hline Genetic (co)variance functions & 113,821 & 225,074 & 18,836 \\
Environmental (co)variance functions & 112,896 & 290,543 & 39,547 \\
Residual variances & 485,709 & $1,531,891$ & 34,199 \\
Additive genetic variances & 123,796 & 291,144 & 50,189 \\
Permanent environmental variances & 163,917 & 562,395 & 64,767 \\
Heritability & 99,102 & 200,074 & 24,548 \\
Genetic correlations & 285,477 & $8,724,325$ & 23,834 \\
Permanent environmental correlations & 216,943 & $9,000,000$ & 32,011 \\
\hline
\end{tabular}



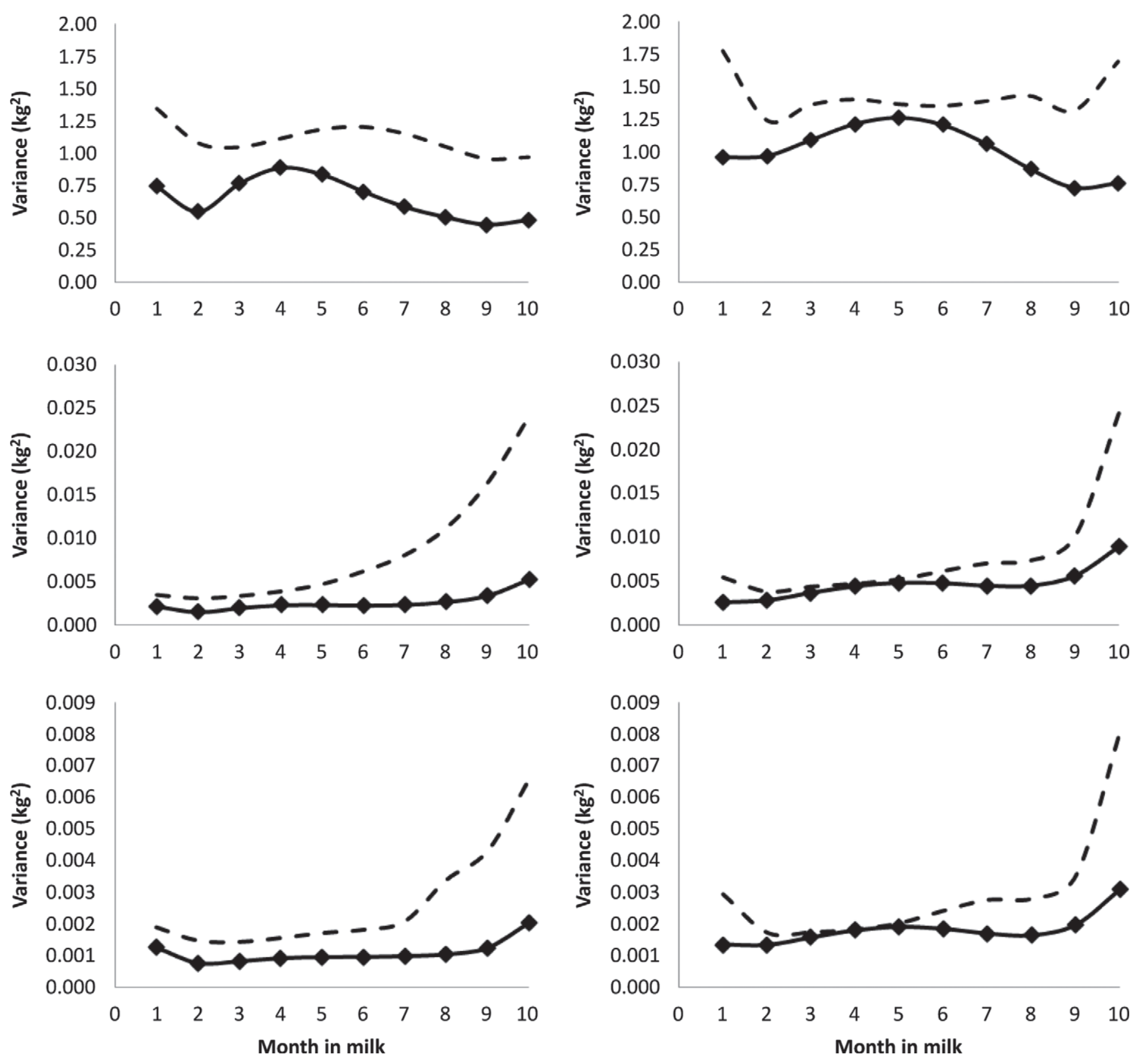

Figure 2. Estimates of additive genetic $(\bullet)$ and permanent environment variances $(--)$ for milk (top), fat (middle), and protein yield (bottom) using single-trait (right) and multi-trait (left) random regression models.

Using random regression models in individual analyses for milk, fat, and protein yields, Aspilcueta-Borquis et al. (2012) reported that for all traits, polynomials of third order were enough to model the additive genetic variance and bigger orders were necessary to adjust the permanent environment (polynomials of fourth order for milk and protein and fifth for fat).

The estimates of additive genetic, permanent environmental, and residual variances for test-day milk yield using single-trait and multi-trait random regression analyses are shown in Figure 2 and Table 3. The additive genetic and permanent environment variance estimates obtained for milk, fat, and protein yield, using single- and multi-trait RRM followed the same pattern; however, higher estimates were obtained with the multi-trait analyses. These results can probably be explained because during the process of regression analysis all the traits were considered in the multi-trait 
Table 3. Posterior mean and highest posterior density region of residual variance $\left(\mathrm{kg}^{2}\right)$ for milk, fat, and protein yield, using single-trait and multi-trait random regression analysis

\begin{tabular}{|c|c|c|c|c|c|c|}
\hline \multirow[b]{2}{*}{ Class } & \multicolumn{3}{|c|}{ Single trait } & \multicolumn{3}{|c|}{ Multiple-trait } \\
\hline & Mean & $\mathrm{LL}^{1}$ & $\mathrm{HL}^{2}$ & Mean & $\mathrm{LL}^{1}$ & $\mathrm{HL}^{2}$ \\
\hline \multicolumn{7}{|l|}{ Milk } \\
\hline 1 & 1.159 & 0.869 & 1.347 & 1.326 & 1.046 & 1.609 \\
\hline $2-3$ & 1.005 & 0.892 & 1.172 & 0.972 & 0.898 & 1.049 \\
\hline $4-8$ & 0.752 & 0.642 & 0.861 & 0.698 & 0.667 & 0.732 \\
\hline $9-10$ & 0.935 & 0.825 & 1.141 & 0.669 & 0.594 & 0.751 \\
\hline \multicolumn{7}{|l|}{ Fat } \\
\hline 1 & 0.346 & 0.250 & 0.429 & 0.364 & 0.279 & 0.443 \\
\hline $2-3$ & 0.306 & 0.231 & 0.381 & 0.302 & 0.277 & 0.326 \\
\hline $4-8$ & 0.402 & 0.284 & 0.543 & 0.316 & 0.300 & 0.330 \\
\hline $9-10$ & 0.528 & 0.405 & 0.912 & 0.651 & 0.515 & 0.839 \\
\hline \multicolumn{7}{|c|}{ Protein } \\
\hline 1 & 0.283 & 0.238 & 0.325 & 0.214 & 0.171 & 0.260 \\
\hline $2-3$ & 0.101 & 0.072 & 0.152 & 0.128 & 0.116 & 0.139 \\
\hline $4-8$ & 0.122 & 0.087 & 0.148 & 0.123 & 0.117 & 0.129 \\
\hline $9-10$ & 0.211 & 0.171 & 0.286 & 0.185 & 0.146 & 0.241 \\
\hline
\end{tabular}

RRM and more information was available to estimate the (co)variance components. The multi-trait RRM makes use simultaneously of all information of each trait evaluated and provides a complete chart of correlations between all traits.

Additive genetic variance for milk yield increased from the beginning of lactation to the fifth month (1.27 $\left.\mathrm{kg}^{2}\right)$ and decreased thereafter until the end of lactation $\left(0.76 \mathrm{~kg}^{2}\right)$. Similar results have been reported by Sesana et al. (2010) working with dairy buffaloes for the midlactation period; however, these authors obtained higher estimates at the extremes of the curve. Using a finite-dimensional (2-trait) model, AspilcuetaBorquis et al. (2010b) reported higher estimates in the third month of lactation and lower estimates at the beginning and at the end of lactation. The permanent environmental variances estimated in the present study were almost constant across lactation, with the observation of slightly higher estimates at the extremes of the curve in agreement with the findings of Sesana et al. (2010).

The variance component estimates for fat and protein yield showed the same trend along the lactation. To date, no studies have reported genetic parameter estimates for fat or protein yield of dairy buffaloes applying the RRM approach. Aspilcueta-Borquis et al. (2010b), using a multi-trait model (finite dimensional model), obtained higher additive variance estimates for fat and protein yield in midlactation, but the shape of the curve was similar to that observed in the present study, except for the last 2 mo of lactation when the estimates increased. In random regression studies for fat and protein yields performed in dairy cattle, the additive genetic variance estimates were higher at the beginning and at the end of the lactation (de Roos et al., 2004; Silvestre et al., 2005; Caccamo et al., 2008). With respect to permanent environmental variance, the estimates showed a similar trend for protein and fat yield, with higher estimates at the beginning and at the end of the lactation curve. This trend has also been reported by Druet et al. (2005) and Hammami et al. (2008) for dairy cattle.

For all the traits, the heritability estimates obtained by single- or multi-trait analyses were different along the lactation, especially at the extreme of the curve (Figure 3). For the multi-trait random regression analysis, smaller amplitude of the interval of high density was observed when compared with single-trait random regression. This is due to the better fit of the curve when all information was considered simultaneously for each trait.

Figure 3 shows the heritability estimates for test-day milk yield in multi-trait random regression analyses. The heritability estimates ranged from 0.23 to 0.38 and they were lower at the extremes of the curve and higher in the fifth month of lactation. The additive genetic variances and heritability estimates showed the same trend, as the permanent environmental variance estimates were almost constant along the lactation. In contrast, Sesana et al. (2010) and Breda et al. (2010) also working with milking buffaloes, using single-trait RRM for weekly test-day milk yield records, reported higher heritability estimates for test-day milk yield at the extremes of lactation.

The heritability estimates for fat yield test-day records in multi-trait random regression analyses, 

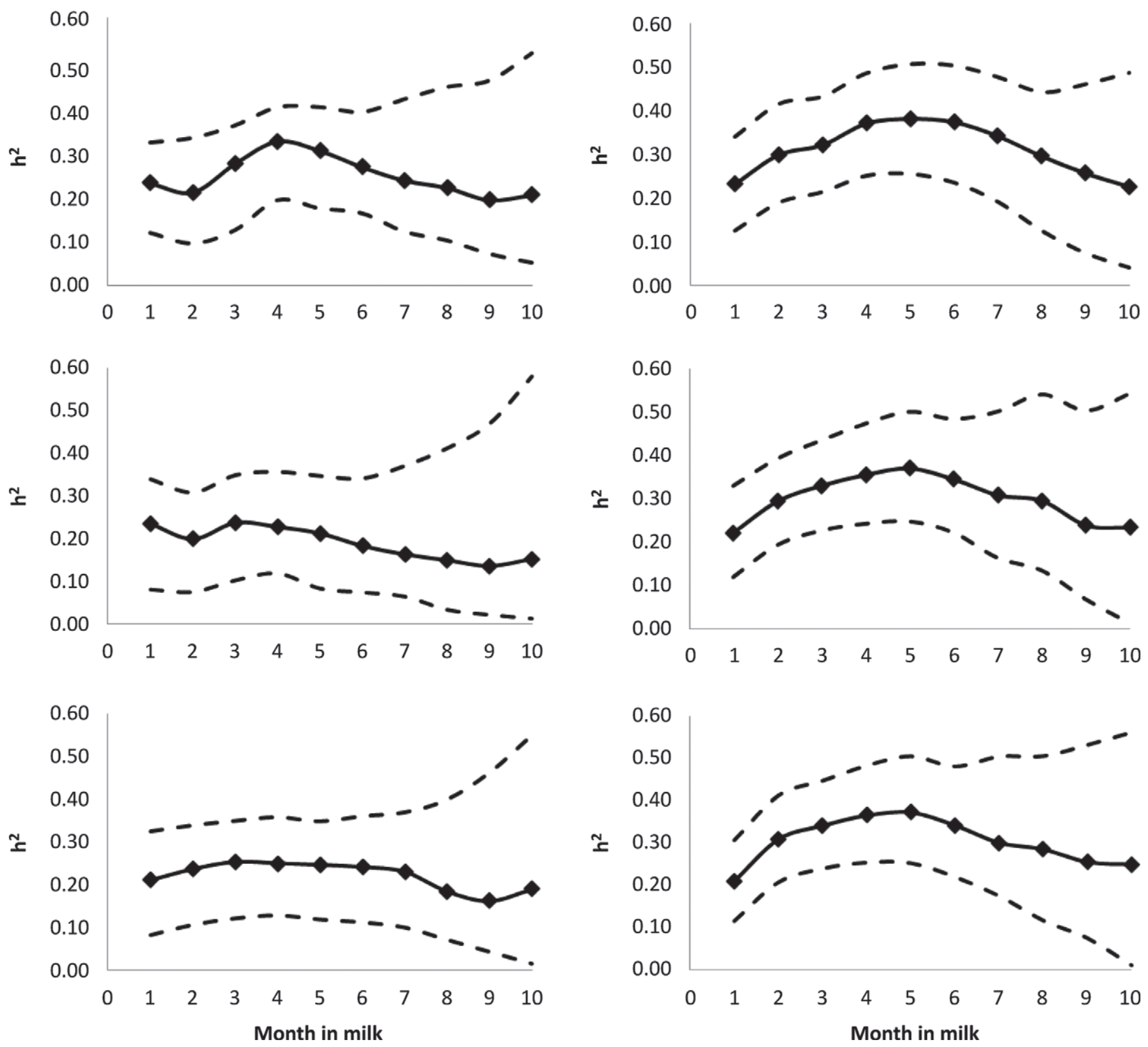

Figure 3. Mean and $95 \%$ of the highest density interval of the posterior distributions of heritability for milk (top), fat (middle), and protein (bottom) yield, using single-trait (left) and multi-trait (right) random regression analysis.

ranged from 0.22 to 0.37 , and they were lower at the beginning and at the end of lactation and higher at midlactation (fifth month; Figure 3). The estimated heritabilities for protein yield test-day records ranged from 0.21 to 0.37 and they were lower at the beginning of lactation and higher in the fourth and fifth month of lactation (Figure 3). Aspilcueta-Borquis et al. (2010b) using a finite dimensional model reported a similar trend of heritabilities for fat and protein yield (monthly) test-day records along the lactation.
However, the authors reported lower heritabilities for fat and protein test-day records, varying from 0.16 to 0.23 and 0.13 to 0.22 , respectively. Using RRM in dairy cattle, de Roos et al. (2004) observed the same trend for fat and protein yield heritability estimates along the lactation. In the study of Hammami et al. (2008), heritabilities for protein yield along the lactation tended to be similar to that seen in the present study; however, the heritability estimates for fat yield were lower in midlactation. 
Table 4. Mean of the posterior distributions of genetic (above the diagonal) and phenotypic (below the diagonal) correlation coefficients between test-day milk $(\mathrm{M})$, fat $(\mathrm{F})$, and protein $(\mathrm{P})$ yield using multi-trait random regression analysis for the lactation mo $2,4,6,8$, and 10

\begin{tabular}{|c|c|c|c|c|c|c|c|c|c|c|c|c|c|c|c|}
\hline Item & M2 & M4 & M6 & M8 & M10 & $\mathrm{F} 2$ & $\mathrm{~F} 4$ & F6 & F8 & F10 & $\mathrm{P} 2$ & $\mathrm{P} 4$ & P6 & P8 & P10 \\
\hline M4 & 0.65 & & 0.97 & 0.87 & 0.36 & 0.91 & 0.98 & 0.94 & 0.75 & 0.18 & 0.91 & 0.98 & 0.94 & 0.75 & 0.17 \\
\hline M10 & 0.22 & 0.30 & 0.32 & 0.53 & & 0.22 & 0.33 & 0.52 & 0.83 & 0.88 & 0.22 & 0.34 & 0.53 & 0.83 & 0.88 \\
\hline F2 & 0.57 & 0.54 & 0.50 & 0.45 & 0.41 & & 0.89 & 0.77 & 0.55 & 0.05 & 0.99 & 0.89 & 0.76 & 0.55 & 0.05 \\
\hline F4 & 0.42 & 0.58 & 0.42 & 0.34 & 0.30 & 0.64 & & 0.95 & 0.71 & 0.10 & 0.88 & 0.99 & 0.95 & 0.71 & 0.09 \\
\hline F10 & 0.13 & 0.13 & 0.28 & 0.33 & 0.45 & 0.23 & 0.38 & 0.49 & 0.57 & & 0.05 & 0.11 & 0.30 & 0.71 & 0.99 \\
\hline P2 & 0.58 & 0.54 & 0.50 & 0.46 & 0.41 & 0.59 & 0.54 & 0.45 & 0.34 & 0.19 & & 0.89 & 0.76 & 0.55 & 0.06 \\
\hline $\mathrm{P} 4$ & 0.42 & 0.58 & 0.42 & 0.35 & 0.30 & 0.44 & 0.49 & 0.35 & 0.30 & 0.21 & 0.63 & & 0.95 & 0.72 & 0.10 \\
\hline $\mathrm{P} 6$ & 0.35 & 0.41 & 0.58 & 0.45 & 0.35 & 0.35 & 0.45 & 0.59 & 0.41 & 0.19 & 0.45 & 0.65 & & 0.87 & 0.29 \\
\hline P8 & 0.28 & 0.29 & 0.36 & 0.46 & 0.32 & 0.25 & 0.36 & 0.41 & 0.49 & 0.36 & 0.35 & 0.40 & 0.51 & & 0.70 \\
\hline P10 & 0.11 & 0.20 & 0.35 & 0.40 & 0.45 & 0.18 & 0.28 & 0.35 & 0.44 & 0.49 & 0.27 & 0.35 & 0.36 & 0.53 & \\
\hline
\end{tabular}

In the current study, the highest estimates are the ones of intermediate test days different from other studies with buffaloes (Breda et al., 2010; Sesana et al., 2010), which observed higher estimates at the extremes of the curve. Curves with lower estimates in the extremes are expected for test-days because they are influenced by factors difficult to control (Hammami et al., 2008). Other authors (Schaeffer, 2000; Misztal, 2006) attributed this poor fit in the extremes to the Legendre polynomials. Poor fit was minimized in this study because a multiple-trait model was used, and all information was considered simultaneously to estimate the genetic parameters and (co)variance components.

The genetic correlation estimates between milk, fat, and protein yield test-day ranged from 0.23 to $0.99,0.05$ to 0.99 , and 0.06 to 0.99 , respectively (Table 4 ). For the 3 traits, the highest genetic correlation estimates were observed between adjacent test days and the lowest correlations between more distant test days. A similar trend has been reported by Sesana et al. (2010) and Breda et al. (2010), using single-trait RRM, for weekly test-day milk yield records in buffaloes. However, these authors obtained unexpected negative genetic correlations between the first and the last test day. Using finite dimensional models, Aspilcueta-Borquis et al. (2010b) estimated higher genetic correlations between milk components test-day records than those obtained in the present study, varying from 0.56 to 0.99 . This difference might be attributed to the model used, as an increase in variances at the extremes of the lactation curve, as well as negative correlations, have been reported with the use of Legendre polynomials (Lopez-Romero and Carabaño, 2003).

The genetic correlation estimates between milk, fat, and protein at the same test day were higher, varying from 0.11 to $0.99,0.12$ to 0.99 , and 0.05 to 0.99 , respectively. In studies with dairy cattle (Hammami et al., 2008), the estimates presented a decreasing tendency, as the distance between the test days are longer but with lower correlation values of test days in the extremes of the curve. The higher correlation estimates obtained in the current study (mainly among traits within test days) may be attributed to the higher proportion of fat and protein of buffalo milk when compared with cattle (Tonhati et al., 2000; Rosati and Van Vleck, 2002; Aspilcueta-Borquis et al., 2010c; Aspilcueta-Borquis et al., 2010d). The low estimates found among the test days in the extremes in comparison to cattle may be explained by the fact that few buffaloes have the potential to produce until the last month considered in the study, at 305 d (Baldi et al., 2011).

Table 5. Mean and SD, minimum (Min), and maximum (Max) of predicted breeding values for milk, fat, and protein yield in buffaloes using single- and multi-trait random regression analysis

\begin{tabular}{lcccrrrr}
\hline & \multicolumn{3}{c}{ Single-trait } & & \multicolumn{3}{c}{ Multi-trait } \\
\cline { 2 - 3 } \cline { 6 - 8 } Trait $^{1}$ & Mean \pm SD & Min & Max & & Mean \pm SD & Min & Max \\
\hline MY305 & $68.78 \pm 88.93$ & -146.24 & 329.36 & & $71.86 \pm 81.31$ & -130.16 & 301.17 \\
FY305 & $2.32 \pm 3.64$ & -6.31 & 13.61 & & $2.62 \pm 2.61$ & -5.44 & 10.15 \\
PY305 & $1.99 \pm 2.81$ & -3.82 & 9.94 & & $2.11 \pm 1.88$ & -2.84 & 8.01 \\
\hline${ }^{1}$ MY305, FY305, and PY305 represent milk, fat, and protein yield truncated and accumulated for 305 d of \\
lactation, respectively.
\end{tabular}


Table 6. Classification of bulls with more than 15 progenies for milk (MY305), fat (FY305), and protein yield (PY305) accumulated for $305 \mathrm{~d}$ of lactation using single-trait (left) and multi-trait (right) random regression analysis

\begin{tabular}{|c|c|c|c|c|c|c|}
\hline \multirow[b]{2}{*}{ Bull } & \multicolumn{3}{|c|}{ Single-trait } & \multicolumn{3}{|c|}{ Multi-trait } \\
\hline & MY305 & FY305 & PY305 & MY305 & FY305 & PY305 \\
\hline 10 & 1 & 1 & 1 & 1 & 1 & 1 \\
\hline 143 & 2 & 3 & 3 & 2 & 2 & 2 \\
\hline 12 & 3 & 4 & 4 & 3 & 4 & 4 \\
\hline 8 & 4 & 5 & 5 & 4 & 5 & 5 \\
\hline 89 & 6 & 2 & 2 & 5 & 3 & 3 \\
\hline 87 & 8 & 6 & 6 & 6 & 6 & 6 \\
\hline 74 & 7 & 8 & 8 & 7 & 8 & 8 \\
\hline 90 & 5 & 9 & 9 & 8 & 9 & 9 \\
\hline 9 & 9 & 7 & 7 & 9 & 7 & 7 \\
\hline 92 & 10 & 10 & 10 & 10 & 10 & 10 \\
\hline 93 & 11 & 11 & 11 & 11 & 12 & 12 \\
\hline 86 & 12 & 12 & 12 & 12 & 11 & 11 \\
\hline
\end{tabular}

Table 5 shows the average of the predicted breeding values with single- and multi-trait random regression analysis for milk, fat, and protein yield. Higher predicted breeding values in multi-trait random regression analysis and a smaller range of high density interval was observed. These differences occurred, probably, owing to higher heritability estimates with a lower range of high density intervals that the multi-trait random regression analysis provided.

In Table 6, the rank correlations are presented for bulls with more than 15 progenies, based on breeding values predicted for MY305, FY305, and PY305 according to single- and multi-trait regression analysis. The breeding values for milk yield obtained with multitrait random regression analysis were used to rank the animals. In both analyses, it could be observed that most of the bulls' positions are coincident for MY305, FY305, and PY305. However, when comparing the positions of MY305 with FY305 and PY305 in both analyses, little overlap exists, indicating that the best bulls for MY305 are not necessarily the best for FY305 or PY305. However, when we look at the rank of FY305 and PY305 a coincidence is observed in both analyses.

For all the traits, the accuracy of predicted breeding values obtained with multi-trait RRM were higher when compared with single-trait RRM (Table 7). Applying a multi-trait RRM, an increase was observed in the average accuracy of evaluated animals of 8.96, 8.77, and 8.62\% for MY305, FY305, and PY305 respectively. The more reliability breeding values obtained with multiple-trait RRM can be attributed to a higher amount of information available from genetic correlations between traits and also due to higher reliable estimates obtained in the multi-trait RRM analyses. The results of the study indicate that heritability estimates for different traits were moderate and the genetic correlations within and among traits varied from moderate to high, indicating that the selection for any test day of any trait will result in indirect genetic gain for milk, fat, and protein yield along the curve.

\section{CONCLUSIONS}

Heritability estimates for all the traits presented moderate values. The genetic correlations estimates varied from moderate to high, demonstrating strong association among traits. The estimates obtained with multiple-trait analyses were more accurate than singletrait analyses, probably due to the higher number of records per animal. Moreover, the possibility to study

Table 7. Number of information (N), mean, SD, minimum (Min), and maximum (Max) values of accuracy of estimated breeding values for milk (MY305), fat (FY305), and protein yield (PY305) accumulated for 305 d of lactation using single-trait and multi-trait random regression analysis

\begin{tabular}{lccccccc}
\hline $\begin{array}{l}\text { Bulls with } \\
\text { more than }\end{array}$ & \multicolumn{3}{c}{ Single-trait } & & \multicolumn{3}{c}{ Multi-trait } \\
\cline { 2 - 3 } \cline { 6 - 7 } 15 progeny & MY305 & FY305 & PY305 & & MY305 & FY305 & PY305 \\
\hline $\mathrm{N}$ & 12 & 12 & 12 & & 12 & 12 & 12 \\
Mean & 0.67 & 0.57 & 0.58 & & 0.73 & 0.62 & 0.63 \\
SD & 0.16 & 0.15 & 0.16 & & 0.14 & 0.16 & 0.15 \\
Min & 0.56 & 0.50 & 0.46 & & 0.61 & 0.52 & 0.50 \\
Max & 0.86 & 0.84 & 0.85 & & 0.95 & 0.92 & 0.90 \\
\hline
\end{tabular}


the relation of milk yield with fat and protein justifies the application of a multiple-trait RRM, although the number of parameters to be estimated are higher. The use of multi-trait RRM, based on the results presented in this study, in addition to enabling the understanding of the correlation between several test days of different traits, indicated an increase in the accuracy of estimates of variance components, heritabilities, and the accuracy of breeding values, as more information is available per animal.

\section{ACKNOWLEDGMENTS}

This study was supported by the State of São Paulo Research Foundation (Fapesp, São Paulo, SP, Brazil) and the National Council of Technological and Scientific Development (CNPq, Brasilia, DF, Brazil).

\section{REFERENCES}

Aspilcueta-Borquis, R. B., F. R. Araujo Neto, F. Baldi, A. B. Bignardi, L. G. Albuquerque, and H. Tonhati. 2010a. Genetic parameters for buffalo milk yield and milk quality traits using bayesian inference. J. Dairy Sci. 93:2195-2201.

Aspilcueta-Borquis, R. B., R. C. Sesana, M. Muñoz-Berrocal, L. O. Seno, A. B. Bignardi, L. El Faro, L. G. Albuquerque, G. M. Camargo, and H. Tonhati. 2010b. Genetic parameters for milk, fat and protein yields in Murrah buffaloes (Bubalus bubalis Artiodactyla, Bovidae). Genet. Mol. Biol. 33:71-77.

Aspilcueta-Borquis, R. R., A. B. Bignardi, L. O. Seno, G. M. F. de Camargo, M. H. Muñoz-Berrocal, L. G. Albuquerque, R. Di Palo, and H. Tonhati. 2010c. Genetic parameters for milk yield analyzed by test-day models in Murrah buffaloes in Brazil. Ital. J. Anim. Sci. 9:179-182

Aspilcueta-Borquis, R. R., R. Di Palo, F. R. Araújo Neto, F. Baldi, G. M. F. de Camargo, L. G. Albuquerque, L. Zicarelli, and H. Tonhati. 2010d. Genetic parameter estimates for buffalo milk yield, milk quality and mozzarella production and Bayesian inference analysis of their relationships. Genet. Mol. Res. 9:1636-1644.

Aspilcueta-Borquis, R. B., F. R. Araujo Neto, F. Baldi, D. J. Santos, L. G. Albuquerque, and H. Tonhati. 2012. Genetic parameters for test-day yield of milk, fat and protein in buffaloes estimated by random regression models. J. Dairy Res. 79:272-279.

Baldi, F., M. M. Laureano, D. G. Gordo, A. B. Bignardi, R. R. Aspilcueta, L. G. Albuquerque, and H. Tonhati. 2011. Effect of lactation length adjustment procedures on genetic parameter estimates for buffalo milk yield. Genet. Mol. Biol. 34:62-67.

Breda, F. C., L. G. Albuquerque, R. F. Euclydes, A. B. Bignardi, F. Baldi, R. A. Torres, L. Barbosa, and H. Tonhati. 2010. Estimation of genetic parameters for milk yield in Murrah buffaloes by Bayesian inference. J. Dairy Sci. 93:784-791.

Caccamo, M., R. F. Veerkamp, G. De Jong, M. H. Pool, R. Petriglieri, and G. Licitra. 2008. Variance components for test-day milk, fat, and protein yield, and somatic cell score for analyzing management information. J. Dairy Sci. 91:3268-3276. de Roos, A. P. W., A. G. F. Harbers, and G. De Jong. 2004. Random herd curves in a test-day model for milk, fat and protein production of dairy cattle in the Netherlands. J. Dairy Sci. 87:2693-2701.

Druet, T., F. Jaffrézic, and V. Ducrocq. 2005. Estimation of genetic parameters for test day records of dairy traits in the first three lactations. Genet. Sel. Evol. 37:257-271.

Gonzales-Récio, O., Y. M. Chang, D. Gianola, and K. A. Weigel. 2006. Comparison of models using different censoring scenarios for days open in Spanish Holstein cows. Anim. Sci. 82:233-239.

Hammami, H., B. Rekik, H. Soyeurt, A. Ben Gara, and N. Gengler. 2008. Genetic parameters for Tunisian Holsteins using a test-day random regression model. J. Dairy Sci. 91:2118-2126.

Heidelberger, P., and P. Welch. 1983. Simulation run length control in the presence of an initial transient . Oper. Res. 33:1109-1144.

Lopez-Romero, P., and M. J. Carabaño. 2003. Comparing alternative random regression models to analyse first lactation daily milk yield data in Holstein Friesian cattle. Livest. Prod. Sci. 82:81-98.

Meyer, K. 2004. Scope for a random regression model in genetic evaluation of beef cattle for growth. Livest. Prod. Sci. 86:69-83.

Misztal, I. 2006. Properties of random regression models using linear splines. J. Anim. Breed. Genet. 123:74-80.

Misztal, I. 2010. BLUPF90 family of programs. Accessed Dec. 12 2011. http://nce.ads.uga.edu/ ignacy/newprograms.html.

Muir, B. L., G. Kistemaker, J. Jamrozik, and F. Canavesi. 2007. Genetic parameters for a multiple-trait multiple-lactação random regression test-day model in Italian Holsteins. J. Dairy Sci. 90:1564-1574.

Pool, M. H., L. G. Janss, and T. H. Meuwissen. 2000. Genetic parameters of Legendre polynomials for first parity lactation curves. J. Dairy Sci. 83:2640-2649.

Rosati, A., and L. D. Van Vleck. 2002. Estimation of genetic parameters for milk, fat, protein and Mozzarella cheese production in Italian river buffalo population. Livest. Prod. Sci. 74:185-190.

Schaeffer, L. R. 2000. Random regression models. Lecture notes. Accessed Apr. 31, 2012. http://www.aps.uoguelph.ca/ /rs/ABModels/NOTES/RRM14a.pdf.

Schaeffer, L. R., and J. Jamrozik. 2008. Random regression models: A longitudinal perspective. J. Anim. Breed. Genet. 125:145-146.

Sesana, R. C., A. B. Biganardi, R. A. Borquis, L. El Faro, F. Baldi, L. G. Albuquerque, and H. Tonhati. 2010. Random regression models to estimate genetic parameters for test-day milk yield in Brazilian Murrah buffaloes. J. Anim. Breed. Genet. 127:369-376.

Silvestre, A. M., F. Petim-Batista, and J. Colaço. 2005. Genetic parameters estimates of Portuguese dairy cows for milk, fat and protein using a spline test-day model. J. Dairy Sci. 88:1225-1230.

Tonhati, H., M. F. C. Muñoz, J. A. Oliveira, J. M. C. Duarte, T. P. Furtado, and S. P. Tseimazides. 2000. Genetic parameters of milk production, fat and protein contents in buffalo milk. Braz. J. Anim. Sci. 29:2051-2056.

Van Der Werf, J., and L. Schaeffer. 1997. Random regression in animal breeding. Course notes. University of Guelph, Guelph, ON, Canada.

Wang, C. S., J. J. Rutledge, and D. Gianola. 1993. Marginal inferences about variance components in a mixed linear model using Gibbs sampling. Genet. Sel. Evol. 25:41-62.

Wiggans, G. R., and M. E. Goddard. 1997. A computationally feasible test day model for genetic evaluation of yield traits in the United States. J. Dairy Sci. 80:1795-1800. 